\title{
PLANNING WITH URBAN CLIMATE IN DIFFERENT CLIMATIC ZONES
}

\author{
Maria-Joao Alcoforado* \\ Centro de Estudos Geográficos \\ Instituto de Geografia e Ordenamento do Território (IGO/UL) - University of Freiburg \\ mjalcoforado@campus.ulpt
}

Andreas Matzarakis

Meteorological Institute - University of Freiburg

andreas.matzarakis@meteo.uni-freiburg.de

\begin{abstract}
Resumen: Se discuten primero los principales cambios climáticos inducidos por los asentamientos, con el fin de establecer los principales objetivos de este trabajo: mostrar la importancia de la información climática para la planificación urbana y hacer hincapié en que las medidas adecuadas "para planificar y construir con el clima" varían de acuerdo con el clima del área donde está localizada la ciudad. Los balances de radiación y energía urbanos, la isla de calor, las condiciones del viento, la contaminación del aire y el confort térmico se tratan en detalle. También son revisados los estudios de las últimas décadas que consideran los beneficios económicos y para la salud de la utilización de información climática. La consideración del clima urbano debe formar parte de los procesos de ordenamiento territorial para lograr una mejor "calidad del clima" en los asentamientos. Se proponen también medidas que pueden reducir los efectos negativos o aprovechar las ventajas de urbanizar una zona basándose en su clima (frío, cálido y húmedo, cálido y árido, contrastes estacionales del clima).
\end{abstract}

Palabras clave: clima urbano, planificación, macroclima, microclima, cambio climático.

Abstract: The main climatic changes induced by settlements are discussed first, in order to introduce the main objectives of this paper: to show the importance of urban climate information for planning and to

\footnotetext{
* Miembro del Jury International de Géographie "Vautrin Lud".
} 
emphasize that adequate measures "to plan and to build with climate" vary according to the macroclimate of the urban area. The urban radiation and energy balances, heat islands, wind conditions, air pollution and thermal comfort are dealt with in detail. Studies of the last decades that consider the economic and health benefits of using climatic information are also reviewed., Urban climates should be a routine consideration of land use planning processes in order to attain a better "climate quality" in settlements. We suggest measures that can reduce the negative effects or take advantage of the positive consequences of urbanization on climate in different climate zones (cold, warm and humid, warm and arid, contrasting seasons' climate).

Keywords: urban climate, planning, macroclimate, microclimate, climate change.

\section{Introduction}

Although urban growth may not be proceeding at very high rates in the developed' world, this is not the case elsewhere, due to "rapid population growth, lack of rural opportunities and perceptions of a better life in cities" (Oke, 1994, p. xxiii). Urbanized areas modify different aspects of climate, from radiation and temperature (the best documented example of human-induced climate change, Oke, 1987), to humidity, precipitation, wind, air quality, among others. Several of these changes have significant impacts upon the comfort, health and safety of city dwellers and impart important costs on their economies. Moreover, in this period of concern for "global" climate change, special attention should be given to cities (Alcoforado and Andrade, 2008).

It is not easy to quantify the impacts of urban climate and still more difficult to calculate its costs. However, a small number of studies have been conducted that deal with the definition of the main impacts of urban climate and present estimates of the mitigation costs of undesired effects of climate change in cities. The limited concern with climate in urban planning to date has been due in part to a lack of systematic research into the relationship of town-planning-climate and of comprehensive climatic design methods (Zrudlo, 1988). However, it is now widely accepted that design which takes into account climate is a benefit, and that climate should be considered at scales from the design of buildings to regional planning (Oke, 1984a; Bitan, 1992; Eliasson, 2000; Koppe et al., 2004; Baumüller, 2008; Alcoforado et al., 2009).

Some of these topics are addressed in this paper. Following a brief review of the urban effects on climate (section 2) we present, in section 3, a discussion of how 
urban planning and building design may minimize urban climate constraints and maximize potentialities in different climate zones. Section 4 lists some of the few studies that deal with the assessment of costs of urban climate. The final section (5) summarizes some natural strategies that can be of use where it is necessary to mitigate the Urban Heat Island (UHI) and related phenomena, control wind speed and promote a high climate quality in town.

\section{Climatic changes induced by settlements}

To a great extent the climate of cities depends on zonal and regional factors, such as latitude, relief, and distance from large water-bodies (Lowry, 1977; Oke, 1984b; Kuttler, 2004). Local and micro-scale factors, such as different characteristics of urban structure, topography and surface cover, modify the regional climate. As a result, a series of local-scale climates are produced within urban areas (Oke, 1987; Matzarakis, 2001; Andrade and Alcoforado, 2008).

\subsection{Energy balance}

The composition of the atmosphere in cities is different from rural areas, due to emissions of gaseous compounds, particles, and water vapour (VDI, 1988; Helbig et al., 1999), as well as decreased wind speed and increased turbulence. As some of the pollutants in the urban atmosphere absorb incoming shortwave radiation (particularly UV-radiation, Table 1), global radiation ( $\mathrm{\downarrow} \downarrow$ ) may be reduced by up to $20 \%$ (Table 1 ). Nevertheless, the complex geometry of urban structures may result in multiple reflections of the short-wave radiation, lowering outgoing solar radiation (reflected by the earth surface, $\mathrm{K} \uparrow)$. However, the albedo $(\mathrm{K} \uparrow / \mathrm{K} \downarrow)$ varies considerably according to solar zenith angle and to land use category (including urban fabric and surface characteristics, Sailor and Fan, 2002). These authors have developed a radiation model that takes into account the diurnal variation of short wave radiation; the model includes the effects of surface shading and radiation exchange among surfaces within the urban canopy layer (UCL), that is, "below the roof tops in the spaces between buildings" (Mills, 2004). The net effect $\left(\mathrm{K}^{*}=\mathrm{K} \uparrow / \mathrm{K} \downarrow\right)$ may be an increase in the absorption of short wave radiation energy by urban surfaces (Oke, 1982; 1988a). In an experimental study conducted in Hong Kong different city districts, Giridharan and Ganesan (2004) showed that air surface temperature increases exponentially when concrete replaces traditional materials, with lower albedo.

Particulate pollutants as well as greenhouse gases in the urban atmosphere may lead to higher downward atmospheric longwave radiation (L $\downarrow$ up to $+10 \%$ on average or up to $21 \%$ in some mega cities of the developing world, Jauregui and Luyando, 
Table 1. Expected characteristics of mid-latitudes towns' climate compared with "rural" nearby areas (Landsberg, 1981; Oke, 1988a; Grimmond and Oke, 1999a; Arnfield, 2003; Kuttler, 2004, modified).

\begin{tabular}{|c|c|}
\hline Parameter & Changes in comparison to rural areas \\
\hline $\begin{array}{l}\text { UV-Radiation (part of } \mathrm{K} \downarrow \text { ) } \\
\text { Summer } \\
\text { Winter }\end{array}$ & $\begin{array}{l}0 \text { to }-5 \% \\
0 \text { to }-30 \%\end{array}$ \\
\hline Global radiation (on horizontal plane) $(\mathrm{K} \downarrow)$ & 0 to $-20 \%$ \\
\hline Albedo $(\mathrm{K} \uparrow / \mathrm{K} \downarrow)$ & 0 to $-7 \%$ \\
\hline Longwave downward atmospheric radiation $(\mathrm{L} \downarrow)$ & 0 to $+10 \%$ \\
\hline Sunshine duration & -5 to $-15 \%$ \\
\hline Sensible heat flux & 0 to $+50 \%$ \\
\hline Heat storage in buildings and surface & 0 to $+40 \%$ \\
\hline $\begin{array}{l}\text { Air temperature } \\
\text {-annual mean } \\
\text {-winter minimum } \\
\text {-in particular cases }\end{array}$ & $\begin{array}{l}\approx+2 \mathrm{~K} \\
\approx+10 \mathrm{~K} \\
\approx+15 \mathrm{~K}\end{array}$ \\
\hline $\begin{array}{l}\text { Wind } \\
\text {-speed } \\
\text {-direction gust } \\
\text {-speed gust }\end{array}$ & $\begin{array}{l}0 \text { to }-20 \% \\
\text { strong varying } \\
\text { higher }\end{array}$ \\
\hline Air humidity & Variable \\
\hline $\begin{array}{l}\text { Fog } \\
\text {-Large city } \\
\text {-small city }\end{array}$ & $\begin{array}{l}\text { less } \\
\text { more }\end{array}$ \\
\hline Clouds & 0 to $+10 \%$ \\
\hline $\begin{array}{c}\text { Precipitation } \\
\text {-Annual } \\
\text {-Rain } \\
\text {-Snow } \\
\text {-Dew }\end{array}$ & $\begin{array}{l}0 \text { to }+10 \% / \text { convective rain) } \\
\text { more (lee side) } \\
\text { less } \\
\text { less }\end{array}$ \\
\hline Condensation nuclei & $\begin{array}{l}\text { about } 10 \text { times more (but smaller } \\
\text { dimensions) }\end{array}$ \\
\hline $\begin{array}{l}\text { Air pollutants } \\
\quad-\mathrm{CO}, \mathrm{NO}_{\mathrm{x}}, \text { Anthr. } \mathrm{VOC}^{1}, \mathrm{PAN}^{2} \\
-\mathrm{O}_{3}\end{array}$ & $\begin{array}{l}\text { more } \\
\text { less (top values higher) }\end{array}$ \\
\hline Vegetation period & 0 to 10 days longer \\
\hline Period of frost & 0 to $-30 \%$ \\
\hline
\end{tabular}

1 Volatile Organic Carbons (VOC).

2 Peroxiacetylnitrate. 
1999) by increasing atmospheric emissivity due to the warmth of the urban boundary layer (Arnfield, 2003). The fact that in an urban canyon $\mathrm{L} \downarrow$ is emitted downwards by the warm building walls is another factor contributing to increase $L \downarrow$. The amount of outgoing long wave radiation ( $\mathrm{L} \uparrow$ ) may be larger in absolute terms compared to rural surroundings, due to higher surface temperatures (according to Stefan-Boltzmann law). However, as urban surface emissivities are slightly lower than typical rural values (Oke, $1988 \mathrm{a}, \mathrm{p} .482$ ) and as the geometry of the urban surface results in reduced sky view factors $(\mathrm{SVF})^{1}$, a decrease of effective $\mathrm{L} \uparrow$ may occur in some urban canyons.

Although the magnitude of each of the radiation fluxes and the overall balance vary spatially, from town to town and from city-district to city-district, the radiation balance $\left(Q^{*}=K^{*}+L^{*}\right)$ is unlikely to vary by a large amount between urban and rural areas" (Arnfield, 2003, p.9). The other terms of the energy balance must also be considered: Anthropogenic heat $\left(Q_{F}\right)$, Latent heat flux $\left(Q_{E}\right)$ and Heat stored in the urban fabric $\left(Q_{S}\right)$. In the absence of advection $\left(Q_{A}\right)$, the remaining energy will be used to heat the air (Sensible heat flux: $Q_{H}$ )

$$
y^{2}+U_{1:}=Q_{i i}+\varphi_{i:}+\Lambda Q_{i}+\Lambda Q_{1}
$$

(Oke, 1987, p.274).

Anthropogenic heat $\left(Q_{F}\right)$ expelled from buildings (due to electricity consumption and heat fuels), released due to transportation and from metabolism of living organisms are sources of heat that cannot be neglected when computing energy balances in urban areas (Oke, 1982; 1988a; Sailor and Lu, 2004). The magnitude of this parameter "depends on each city per capita energy use and its population density. The former depends on many factors including climate (due to the demand for space heating and cooling), the degree and type of industrial activity, the site of electricity generation (e.g. thermal power plants in the city or import from afar)" (Oke, 1988a, p.485). The highest values occur in densely inhabited areas in cold climates. The heat emitted from traffic, from wall-mounted air conditioners, subway vents or poorly insulated subterranean heating pipes will most certainly have a direct impact on the heat balance of the urban canopy layer (Oke, 1988a).

Several authors gave evidence that anthropogenic heat must be introduced in urban energy balance modelling. Kannari et al. (2003) concluded that the introduction of $Q_{F}$ in urban canopy layer energy balance model for Tokyo results in a temperature rise of circa $1^{\circ} \mathrm{C}$. Sailor and Lu (2004) describe a methodology to compute $Q_{F}$, without gathering building level energy data (not only time-consuming, but also

\footnotetext{
${ }^{1}$ The sky view factor is "the ratio of the amount of sky 'seen' from a given point on a surface to that potentially available (i.e. the proportion of the sky hemisphere subtended by a horizontal surface)" (Oke, 1987, p. 404).
} 
prohibitively expensive). The three types of $Q_{F}$ (released from buildings, traffic and metabolism) are computed based on hourly population density data, as well as on transportation statistics, using "readily available data" (Sailor and Lu, 2004, p.2746). The authors computed summer and winter diurnal anthropogenic heating profiles of $Q_{F}$ for six large US cities, and confirmed that the magnitude of $Q_{F}$ depends on population density. Heating from vehicles constitutes accounts for 47 to $62 \%$ of the total. During winter months heating fuels increase in cold cities (e.g. 51\% in Philadelphia and $57 \%$ in Chicago). Metabolic heat makes up only 2 to $3 \%$ of the total heating for all cities studied by Sailor and Lu (2004). According to the authors, one of the goals of the research is to "enable the inclusion of detailed anthropogenic heating data in fine grid ( $1 \mathrm{~km}$ grid scale) mesoscale atmospheric simulations of urban environment" (Sailor and $\mathrm{Lu}, 2004$, p. 2747). As the urban core region may have a daytime population density from 2 to 10 times that of the city scale value, Sailor and Lu (2004) refer that the corresponding anthropogenic heating values in the city centre can still be 2 to 10 times higher than those computed by them.

Furthermore, urban materials have a higher thermal admittance (ability to store and release heat) and most of them are impervious. As a result, there is an increased heat storage $\left(Q_{S}\right.$, up to $+40 \%$, Table 1$)$, and a decrease of evaporation and consequently of turbulent latent heat $\left(Q_{E}\right)$ in urban areas (Oke et al., 1991; Helbig et al., 1999). Grimmond and Oke (1999a) conclude that storage heat flux is a significant component of surface energy balance of seven US cities, that $Q_{S}$ is greatest at downtown and light industrial sites and that it varies between 17 to $58 \%$ of the daytime net radiation.

Bowen ratio is frequently higher in cities than in their surroundings, although in some regions that are extremely dry, urban areas may have greater latent heat flux (Grimmond and Oke, 1999b). High building density acts as an obstacle to air flow, as buildings increase aerodynamic surface roughness. The decrease of wind speed due to urban roughness (down to $-20 \%$, Table 1 and $\mathbf{1 . 4}$ ) contributes to decreased turbulent heat exchange and sensible heat loss $\left(Q_{H}\right)$ from urban canopy layer (up to $+50 \%$ sensible heat flux in urban areas, Table 2 ).

\subsection{Temperature and the urban heat island}

The factors listed in the preceding discussion are the main energetic causes of the urban heat island (UHI), one of the most well-known urban climate features. The maximum UHI intensity ( $\mathrm{UHI}_{\max }$ ) is the difference between the background rural temperature and the highest sustained urban temperature (Oke, 1987; Oke, 2006). There are several types of UHI: sub-surface, surface, near surface air in the urban canopy layer (UCL) and air above roof level in the urban boundary layer (UBL) (Oke, 2006). Most of the information introduced in this text refers to UCL UHI (if not, UHI type 
will be explicitly indicated). UHI varies both in space and time and may be replaced by a negative heat island or cool island during daytime. According to Oke (1987), the most important factors for the formation of the UHI in the UCL are the lower free horizon (smaller sky view factors, which results from urban geometry, Ib, Table 2) and the higher thermal admittance of the building materials (IVa, Table 2). On average annually air temperature in cities is up to $2 \mathrm{~K}$ higher than in rural surrounding areas, and in special cases during the night under clear sky conditions and for short periods the differences may reach $15 \mathrm{~K}$ (Oke et al., 1991; Matzarakis, 2001).

Table 2. Main causes of the canopy layer heat island of towns (after Oke, 1987, p.294 and Sailor and Lu, 2004).

\begin{tabular}{|l|l|}
\hline \multicolumn{1}{|c|}{ Town Characteristics } & \multicolumn{1}{c|}{ Energetic effects } \\
\hline $\begin{array}{l}\text { I. Urban Canyon Geometry } \\
\text { a) increased surface area and multiple } \\
\text { reflection } \\
\text { b) reduction of sky view factor } \\
\text { c) decrease of wind speed }\end{array}$ & $\begin{array}{l}\text { Increased absorption of short wave radiation } \\
\text { Decrease long wave radiation loss } \\
\text { II. Air Pollution - greater absorption and } \\
\text { re-emission }\end{array}$ \\
$\begin{array}{l}\text { III. Heat emission from buildings, traffic } \\
\text { and living organism metabolism }\end{array}$ & $\begin{array}{l}\text { Increased downward atmospheric radiation } \\
\text { IV. Building materials } \\
\text { a) increased thermal admittance } \\
\text { b) increased "water-proofing" }\end{array}$ \\
$\begin{array}{l}\text { Anthropogenic induced heat } \\
\text { Increased sensible heat storage }\end{array}$ \\
\hline
\end{tabular}

As a direct consequence of the UHI, the frost period may be up to $30 \%$ less frequent in cities and the vegetative period up to 10 days longer (Table 1).

Figure 1 (Wienert, 2002) shows the relationship between UHI $_{\max }$ and cities at different latitudes. The analysis is based on 150 cities. For the sake of comparison, only the absolute values of the latitude are shown.,UHI maximum intensity appears to increase with latitude albeit in an inconsistent way The results must be handled with care because UHI maximum values were not always comparable, as different methods to compute it were used, as expressed by several authors (Kim and Baik, 2004; Oke, 2006). Furthermore, metadata from the meteorological stations were not always indicated. A later publication on the same study (Wienert and Kuttler, 2005), states that heat island intensity of the studied cities depend mostly on $Q_{F}$ and $Q^{*}$ and that 


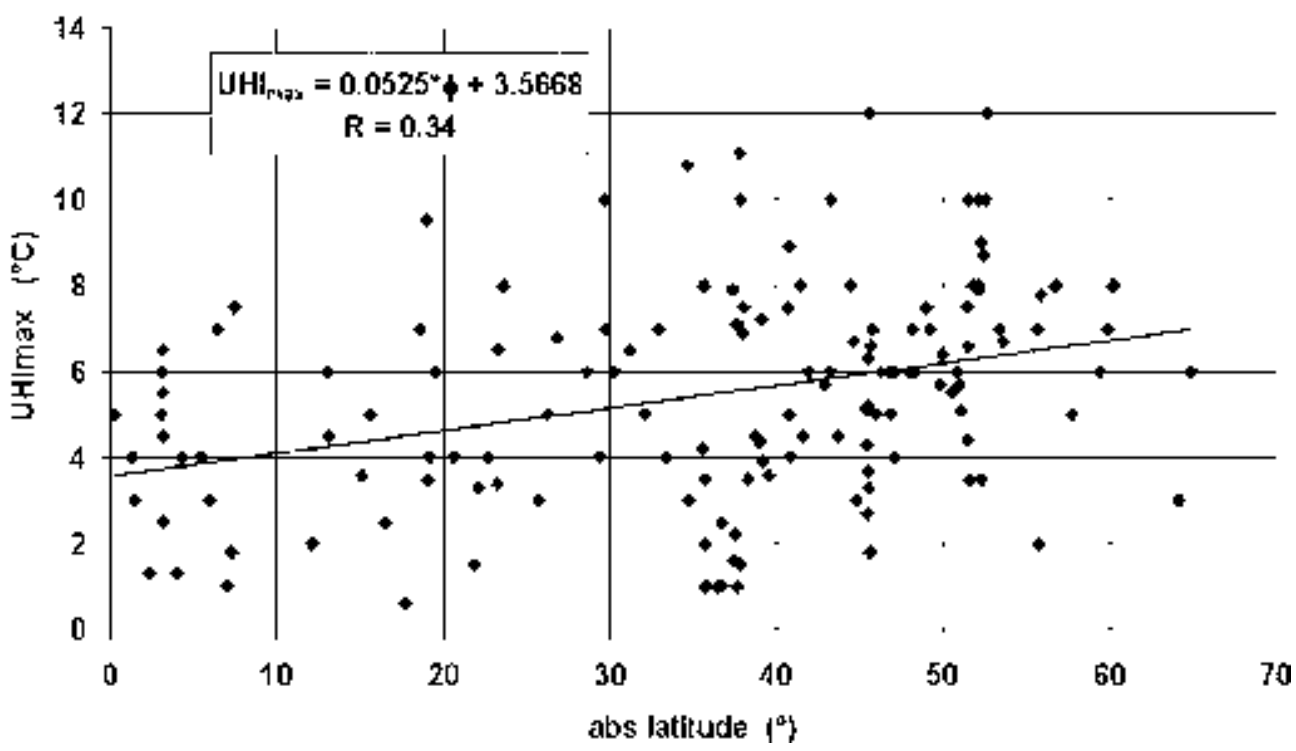

Figure 1. Maximum UHI and absolute latitude for 150 cities (after Wienert, 2002).

the variation of UHImax with latitude may be "caused by the appropriate latitudinal dependence of anthropogenic heat production and radiation balance" (p.685). However, one should bear in mind the regional climate variation at the same latitude due to other geographical factors, such as altitude and distance from the sea, which will in turn influence the factors that cause UHI. This may explain the wide dispersion of values in Figure 1.

The lowest values of $\mathrm{UHI}_{\max }$ were obtained in the tropics. Cities in wet climates or surrounded by wetlands, rain forest or paddy fields tended to have lower UHI, due to increased rural thermal admittance of the wet soil reducing rural cooling (Oke et al., 1991). This has been observed in Lagos, Bogota as well as in Kuala Lumpur and Singapore and other Asian cities (Oke et al., 1991; Tso, 1996). According to Oke et al. (1991), other factors may explain small UHI in tropical cities: i) high albedos and the "shade effect" reduce solar radiation absorption and produce a negative day-time canopy layer UHI, leading to a decrease of heat storage in the fabric and, consequently, lower UHI in the succeeding night; ii) an irrigation-driven oasis effect may also originate a negative UHI island at sun-set.

The positive residuals (higher $\mathrm{UHI}_{\max }$ ) correspond to tropical cities with a distinct dry season (Oke et al., 1991; Jauregui, 1997). On the other hand, the suburbs and the 
nearby rural areas of some other large or medium-size tropical cities (like Mexico City and Dakar) have low-cost one or two storey dwellings and mostly unpaved roads; the vegetation is sparse the whole year round or just during the dry season (Jauregui, 1997). In these cases high nocturnal UHI occur, which are increased by radiative cooling of the suburbs. If air conditioning is used some systems vent hot air to the exterior warming the atmosphere, which may increase the UHI.

Few cities are located in high latitudes. However, studies from Fairbanks, Alaska (Magee et al., 1999), Reykjavik (Steinecke, 1999) and Moscow (Shahgedanova, et al., 1997 ) indicate that in winter UHI may be very large (up to $11^{\circ} \mathrm{C}$ in Fairbanks, Magee et al., 1999), particularly if the rural surroundings are covered by snow. During this season, anthropogenic heat plays a very important role as a causal factor of the UHI (Oke et al., 1991, Steinecke, 1999). However, in Reykjavik UHI is rather low (maximum $1^{\circ} \mathrm{C}$ during spring dawns) and an urban cool island occurs during summer afternoons, mostly due to low solar elevation giving rise to shadow effect.

There are other reasons that explain the fact that the statistical relation between the $\mathrm{UHI}_{\max }$ and latitude $\mathrm{f}$ (Figure 1) is not very strong. It is well known that the UHI depends on many other factors, at different spatial scales. For several cities, it has been possible to establish numerical relationships between canopy layer, air temperature and different geographical parameters at different spatial scales: mesoclimatic or local factors such as altitude, relief index, distance to the sea, and microclimatic factors such as sky view factor and building density. See, for example, Bärring and Mattsson (1985); Eliasson (1990-91; 1996); Oke et al. (1991); Alcoforado (1994); Upmanis (1999); Pearlmutter et al. (1999); Goh and Chang (1999); Svensson et al. (2002); Andrade (2003); Alcoforado and Andrade (2006). Other papers such as Sakakibara (1996), Masson (2006),; Martilli (2007) and numerous others listed in Arnfield (2003), Atkinson (2003), Kusaka and Kimura (2004) and Alcoforado (2010) present numerical modelling, which is another approach to increase the understanding of the UHI. Through a three-dimensional, non-hydrostatic, high-resolution numerical model, Atkinson (2003) studied London's UHI. He conducted a series of experiments "in which successively each one of the anomalies that represent the urban area was omitted from the control simulation so as to provide a basis for an assessment of its effect" (Atkinson, 2003, p.306). During the night the largest effect was due to $Q_{F}$ although emissivity, $Z_{0}$ (see 2.4 ), SVF and surface resistance to evaporation also contributed to UHI.

In addition to the features of the urban climate described above, other climatic variables are relevant to human comfort and town planning and show differences in urban areas. These are briefly described below. 


\subsection{Humidity, rain and snowfall}

Although relative humidity may be lower in the urban atmosphere, due to higher temperature, absolute humidity may be higher, notably at night (Oke, 1995; Jauregui and Tejeda, 1997; Holmer and Eliasson, 1999; Deostali, 2000; Mayer et al., 2003). The 'urban moisture effect (UME)' within the urban canopy layer may be due to reduced dewfall, anthropogenic vapour and the stagnation of airflow (Oke, 1987, p. 295). Studies on dew in urban environments remain limited (Richards, 2004). Although visibility may sometimes be lower in cities, dense fog is less frequent in urban areas (Landsberg, 1981).

In some situations, urban cloud cover may be up to $10 \%$ higher, as well as precipitation (mostly convective summer rain falling on the lee side of the cities (Atkinson, 1971; Changnon, 1974; Jauregui and Romales, 1996; Shepherd, 2005). Lowry (1998) provides a comprehensive review of urban effects on precipitation, notably intensified convective precipitation on the lee-side of cities were considered due to urban increased surface roughness and condensation nuclei, as well as higher air temperature. Subsequent work has focused on intensification of convective precipitation (Bornstein and Lin, 2000; Grady and Mote, 2003; Rozoff et al., 2003). The effect of urban condensation nuclei in enhancing precipitation has also been denied; based on satellite data, Rosenfeld (2000) provides evidence that urban and industrial pollution suppresses precipitation, due to inhibition of cloud droplet coalescence.

In Shepherd (2005) a synthesis of this topic and a long reference list since the $1990 \mathrm{~s}$ is to be found. The author also states that further monitoring of land use, particulate matter, cloud microphysics and precipitation (using radars) is still lacking to develop modelling at different spatial scales, to validate the simulations and fully understand the phenomenon.

According to Oke (1987), there is "conflicting evidence regarding the influence of snowfall". In fact, in Berlin, Paris, Lund, among others, there is evidence that snowfall is up to $30 \%$ lower over cities than over the rural nearby areas (Landsberg, 1981). This could be explained by the fact that UHI may be sufficient to melt flakes over the city (Oke, 1987).

\subsection{Wind}

\section{Mean wind speed}

Urban areas contribute to slow mean horizontal wind speed, as drag caused by urban elements retards motion close to the ground. The Ekman-layer power law provides a good fit for the wind profile 


$$
U(z)=V_{i r} \cdot\left(\frac{z}{z_{i i}}\right)
$$

(Davenport, 1965), where $U$ is the wind speed $\left(\mathrm{ms}^{-1}\right)$ at height $z(\mathrm{~m}), U_{G}$ is the geostrofic wind $\left(\mathrm{ms}^{-1}\right)$, and $Z_{G}(\mathrm{~m})$ is the height at which geostrofic undisturbed flow occurs. The $\boldsymbol{\alpha}$ exponent was given by Davenport for flat areas (0.16), suburban areas (0.28) and urban core (0.40). Wind profiles show that the height at which geostrofic flow is encountered increases in the urban core where roughness is greater (Oke, 1987). According to Davenport (1965), for neutral conditions, mean $Z_{G}$ goes up to $270 \mathrm{~m}$ over rural areas, $390 \mathrm{~m}$ over suburbs and $420 \mathrm{~m}$ over the urban core. "In light winds, $Z_{G}$ also depends on the amount of thermal convection generated at the surface" (Oke, 1987, p. 54).

However, in the turbulent surface layer (Oke, 1987, p. 5), generated by surface roughness and convection, under neutral stability

$$
\left(i(z)-\frac{U i}{\hbar} \ln \frac{Z}{Z}\right.
$$

where $U(z)$ is the mean wind speed $\left(\mathrm{ms}^{-1}\right)$ at height $z(\mathrm{~m}), U_{*}$ the friction velocity, $k$ von Karman constant $(\sim 0.4)$ and $Z_{O}$ the roughness length $(\mathrm{m}) . \mathrm{U}_{*}{ }^{2}=\tau / \rho$, where $\tau$ is the shearing stress and $\rho$, the air density.

$Z_{O}$ is a measure of the aerodynamic roughness of the surface, related to the height of roughness elements. Oke (1987, p. 57) defines it as "the height at which the neutral wind profile extrapolates to a zero wind speed".

$Z_{O}$ can also be calculated for solid obstacles following Lettau's equation (1969)

$$
Z_{: t}=\left\{k n \frac{5}{s}\right.
$$

where $b$ is the mean height of the obstacles, $s$ the mean wind exposed area and $S$ the specific ground area of the obstacle. In the case of multiple obstacles (amount $\mathrm{n}$ ) in an area $A$, then $s=A / n$. For vegetated surfaces, $Z_{0}$ may be estimated from the following equation (Wilmers, 1997):

$$
\log Z_{O}=1.03 \log h_{O}-0.86
$$

where $b_{0}$ is the average height of plants. Kondo and Yamatawa (1986) give an additional approach for vegetated surfaces with $Z_{0}$ being $12.5 \%$ of the mean height of the vegetated surface.

The renewal of air in an urban area depends on air flow, which in turn is regulated by the urban fabric (building dimensions, orientation, percentage of free space, 
spatial arrangement). However, urban fabric also gives rise to eddies between and around buildings (Oke, 1987), free spaces channel the wind and sheltered areas are created (mostly in narrow streets aligned at right angles to the mean flow, Wilmers, 1997). Grimmond and Oke (1999c) give a general overview of the changes in flow regimes, according to the relation between $Z_{0}$ and $Z_{d}$ (zero-plane displacement, Rotach, 1994ii) and make recommendations concerning methods to estimate $Z_{0}$ and $\mathrm{Z}_{\mathrm{d}}$ through analysis of surface form and spatial distribution of roughness elements. Lopes et al. (2011) give an example referring to Lisbon.

\section{UHI circulation}

On the other hand, on calm and clear occasions, when a UHI occurs, a flow of cooler (and cleaner) air is induced between the rural and the urban areas: this is named country breeze (Barlag and Kuttler, 1990/91) or urban heat island circulation (Holmer and Eliasson, 1999). In those days wind speed may be slightly higher in the city than in the nearby rural area.

\section{Sea breezes}

When it comes to wind in the city, sea breezes should also be considered, as UHI intensities may vary considerably. In several seaside cities, such as Lisbon (Alcoforado et al, 2006, 2007), Nice (Carrega, 1994) ${ }^{2}$ and Colombo (Emmanuel et al., 2006) seashore districts are particularly cool under sea breezes occasions, even if on other occasions they are the warmest spots of the urban area.

\section{Problematic urban climate aspects in different regions}

In order to provide the best conditions of well-being and health for the inhabitants of urban areas, all aspects of the atmosphere must be taken into account (VDI, 1998; Scherer et al, 1999; Baumüller, 2008). Thermal, ventilation and air quality factors are the main atmospheric components modified in a city, although other factors like noise and odours should also be considered (Wilmers, 1997; Baumüller, 2008; Matzarakis et al., 2008). In regions where flash floods are likely to occur, precipitation intensity must be studied in detail. However, "it is widely accepted that the question "which

\footnotetext{
${ }^{2}$ Zero-plane displacement $\left(Z_{\mathrm{d}}\right)$. The zero plane displacement, like $\mathbf{Z}_{\mathbf{0}}$, is empirical. For tightly packed roughness elements, the top of the elements can appear to the flow to be like a surface. For example, the canopy top of a dense forest can have this effect. The height above the ground of this pseudo-surface is called the zero plane displacement. For a situation with no zero plane displacement, the mean wind is zero at height $\mathbf{Z}_{\mathbf{0}}$. For a situation with a displaced zero plane, the mean wind is zero at height $\left(Z_{d}+\mathbf{Z}_{\mathbf{0}}\right)$.
} 
urban forms make the best use of land?' cannot have an absolute answer. There are too many parameters to consider, each of which will have its own effect. Moreover, when a large number of environmental variables are taken into account, it is likely that conflicts amongst them will emerge and so terms such as 'best' and 'optimum' best describe decisions ultimately made" (Ratti et al., 2003, p.54).

Aynsley and Gulson (1999) and Mills (2006) argue that urban climates should be a routine consideration of land use planning processes. The following discussion is structured within the framework of a city's macroclimate to highlight which aspects of urban climate should be addressed in town planning. Following Brazel and Martin (1997), climates will be classified in a very simple way as "Hot climates" (subdivided in "Hot humid climates" and "Hot arid climates"), "Cold climates" and "Others". Within "other" climates examples are included of regions with more than one type of stressful season. These climates are grouped under the designation of "Climates with contrasting seasons".

\subsection{Hot climates}

In cities with hot climates, the UHI is one of the most negative factors, not only on human comfort and heat stress, but also on human health (Oke, 1994; Koppe et al., 2004; Gill, 2004; Gosling et al., 2009). Moreover, it has negative effects on energy use (more demand for air-conditioning), water use, air pollution meteorology (increased re-circulation/fumigation effects), air pollution chemistry (secondary transformation) and possibly on precipitation (Oke, 1994; Jauregui, 1997). Therefore, it is advantageous for human health and economy to mitigate its effects.

\subsubsection{Hot humid climates}

In this section, we will look into areas in a band of latitudes 10 to $15^{\circ}$ north and south of the equator, where high temperatures persist all the year round $\left(27{ }^{\circ} \mathrm{C}\right.$ on average), with a small diurnal temperature range and maximum temperatures higher than $30^{\circ} \mathrm{C}$ and minimum between 20 and $24^{\circ} \mathrm{C}$. High humidity values and low wind speed (e.g. equatorial doldrums) are other characteristics that contribute to maximize heat stress. Rainfall varies considerably from place to place, but there is no true dry season. In some areas of higher latitudes than $15^{\circ}$, located at the eastern parts of the continents (SE United States, SE China and south Japan, E Australia, etc) very hot and humid summers cause strong heat stress on human beings, mostly during night-time (Moriyama and Matsumoto, 1988). In these areas the main strategies ${ }^{3}$ to minimize

${ }^{3}$ Detailed strategies are referred in 5 . independently of regional climate. 
heat stress are: a) to provide or maximize ventilation in and around buildings. Buildings should be as loosely dispersed as possible. In settlements near the shore, any obstructions that affect the penetration of the sea breeze should be avoided. In such settings, urban canyons should be aligned with the dominant sea-breeze direction (Golany, 1996; Emmanuel and Johansson, 2006); b) to reduce solar radiation. Shading of urban spaces is indispensable, either by purpose-built shade structures, the appropriate combination of height and orientation of buildings, or strategically positioned and selected vegetation. "; c) to minimize potential hazards from flooding (Brazel and Martin, 1997); d) to promote evaporative cooling, that may improve thermal comfort, but only in spaces that are reliably well ventilated during the critical late morning and afternoon hours (Lin et al., 2010, Hwang et al., 2011).

\subsubsection{Hot arid climates ${ }^{4}$}

The dry regions occur not only in the subtropical latitudes, but also in continental locations at mid and high latitudes. Very high diurnal air temperature ranges are one of the main climatic features, as well as very low air humidity values. Air temperature can swing from $50^{\circ} \mathrm{C}$ during the day to $15^{\circ} \mathrm{C}$ or lower overnight (Brazel and Martin, 1997).,Stronger seasonal temperature variations occur at higher latitudes and in winter temperatures go down to negative values. The main measures to minimize climatic stress are the following: a) to reduce solar gain. Strategies to minimize heat stress must be pursued in order to avoid air conditioning. For example trees (Shaashua-Bar and Hoffman, 2003), arcades and narrow streets (Baker et al., 2002) and different shade devices can be used to reduce radiation and thus diminish heat loads (Jendritzky, 1988), as well as using high-albedo materials as building surfaces (Akbari et al., 2001; Sass, 2003; Doulos et al., 2004). Green roofs (Kumar and Kaushik, 2005); b) to maximize solar gain in winter (and during cool nights). Most of the measures referred to in a) are directed to creating more pleasant thermal conditions in continuously hot climates, but not directed towards winter low temperatures in high latitude deserts or continental dry mid-latitude areas. However, if building material and wall thickness is correctly chosen, then diurnal temperature variations inside the buildings can be minimized, taking advantage of the heat storage capacity of the walls (Brazel and Martin, 1997; Offerle et al., 2005); c) to increase the extent of evaporation. In order to balance net radiation at the ground surface by latent heat loss, the extent of evaporation must be increased. This can be achieved by reducing the non-permeable surfaces, and designing irrigated greenbelts within the communities (Bonan, 2000). In arid and semi-arid areas of the US, the Bowen ratio decreases as the area of irrigated green space increases (Grimmond and Oke, 1995). In the experiment conducted by Bonan (2000) in different neighbourhoods of hot and dry Boulder County community, the importance of irrigation was well established, when

${ }^{4}$ Within this topic, references will also be made to higher latitudes dry climates. 
comparing surface temperature of native grass with heavily watered residential or park lawns. The former was a few degrees warmer than the latter; d) to minimize wind exposure (Brazel and Martin, 1997; Givoni, 1998), by building within the smallest possible building envelope. Brazel and Martin (1997) suggest the importance of compact geometry and short walking distances to avoid extreme conditions Pearlmutter et al (2007) agree that "increased urban density, while serving to increase radiative trapping and storage of heat within the urban fabric, also reduces thermal stress during the critical daytime hours". This effect is due to high thermal inertia of the buildings and to great diurnal temperature amplitudes, with relatively low minimum temperatures. However North-South street orientation is the best to attain the cooling effect in the urban canyons (Pearlmutter et al., 2007).

\subsection{Cold climates}

This section deals with high Northern hemisphere latitude climates (North of $55^{\circ}$ ) characterized by low temperatures all the year round, including a cool summer and strong winds.

There are only a few papers on urban climates in high latitude climates. For example, in Reykjavik (64- N; Steinecke, 1999), a weak heat island occurs all day long in winter, a consequence of extra energy from geothermic pavement heating and above ground hot water tanks and pipelines. In summer, however, the urban area is cooler (a cool island) during daytime due to shadowing of the urban sites due to low solar altitude, as well as of the cooling effect of the ocean close to the city centre. Most valley bottom locations are unsuitable for developing new neighbourhoods, on account of cold air drainage and accumulation (Steinecke, 1999). Although wind speed is drastically reduced within the densely built-up area of Reykjavik (from $4 \mathrm{~m} \mathrm{~s}^{-1}$ to $1.8 \mathrm{~m} \mathrm{~s}$ ${ }^{1}$ ), certain buildings cause "erratic gusts" in the city centre, creating very unpleasant microclimates especially when wind chill factors are concerned.

Brazel and Martin (1997) describe the Eskimo house as an excellent example of design adapted to climate. Referring to modern buildings the main measures to minimize climate stress in cold areas are the following: a) to maximize solar gain by avoiding light-coloured materials in order to lower albedo (Sailor, 1995); a dense urban fabric will also contribute to minimize short-wave radiation reflection (Sailor and Fan, 2002) and to minimize heat loss; b) to favour the UHI as its effect is positive. This can be achieved by minimizing heat loss using compact forms and good insulation; windows should be located on walls facing the sun to enhance $\mathrm{K}$ absorption; c) to minimize wind exposure all the year round, except in neighborhoods where windy conditions are necessary to improve air quality. Bullen (2000) discusses the need of more appropriate design in coastal areas of northern and western 
Scotland, characterised by windy conditions and abundant rain, that calls for high insulation, air-tightness and controlled ventilation to enhance indoor comfort of the inhabitants and to minimize the effects of driving rain.

Zrudlo (1988) presents a methodology for town planning in the Arctic, where each specialist would be assigned the task of producing a plan for each important climatic factor to be controlled in cold climates: sun, wind and snow. Solar aspects, wind-protection requirements and snow accumulation control would be mapped separately. The next step involves the identification of conflicting requirements between plans. Consultation and negotiation are then necessary to reach a compromise. The final result is a synthesized plan, which offers maximum solar advantage, wind protection, and minimum snow-drifting, contributing to the general well-being, both physical and psychological, of the inhabitants. The same methodology can be applied elsewhere, provided that the climatic factors to be controlled are chosen according to site macroclimate.

\subsection{Climates with contrasting seasons}

"Regions with more than one stressful season present a special challenge to climatologists, planners, and architects because one season can often require conflicting design solutions to the other seasons" (Brazel and Martin, 1997, p.180). Included in this category are different types of climates, as "temperate" climates, with contrasting thermal and rainfall seasons (both western and eastern parts of the continents), dry climates with alternation of extreme temperatures (the latter have already referred to in 3.1.2). A compromise between the different design solutions discussed is often required. If the prevailing favourable winds (e.g. fresh/cool summer wind) blow from a different direction than the ones with negative consequences (e.g. cold winter winds), then it will be easy for the planner or the architect "to accomplish a successful design that encompasses both seasonal strategies" (Brazel and Martin, 1997, p.180). Problems arise if favourable and negative winds blow from the same direction.

In the urban areas of the eastern continental parts of extratropical regions the wind chill and heavy blizzard events, often combined with freezing rain during winter, create quite miserable living conditions. An underground city center was built in Montreal to offset these weather events (Helminen, personal communication). However, very few urban communities can afford this kind of solutions. In the summer, however, the inhabitants of the same areas have to fight against very hot and moist weather and frequent heat waves (as in July 2005).

With respect to "temperate" climates with contrasting seasons, the UHI is favourable in winter but threatens human comfort and health in summer. Athens, 
Lisbon and Los Angeles are examples of "Mediterranean type" climates, where the answer to the following question is not easy: is the UHI positive or negative? The same question may be asked in the cases for example of south-eastern China and south Japan. Ettoumi et al. (2003), in a study of the semi-arid region in Algeria where very low temperatures occur in winter and very high temperatures are expected in the summer, report that cheap traditional materials with greater thermal inertia can effectively be used for housing constructions. Oral and Yilmaz (2003), drawing on work from Turkey, conclude that in order to satisfy thermal comfort and reduce heating energy consumption, building form and building envelope must be determined properly during the planning stage. Numerous papers refer to the decrease in human comfort in cities (Katzschner, 1988; Matzarakis et al., 1999; Chen et al., 2004).

Besides economical consequences, increasing attention is being paid to the health effects in a world where global warming is occurring (Jackson, 2003; Koppe et al., 2004; Alcoforado and Andrade, 2008). Situations will, of course, be even worse in cities with increasing UHI and many municipal governments of so-called "temperate" climates with contrasting seasons have decided to take measures to mitigate urban heat island, even if this feature could have some advantages in winter.

\section{Benefits derived from solving problematic urban climate features}

\subsection{Economical benefits}

There are still very few studies assessing the costs and benefits of modifying climate constraints. However, some works point out different possible options for reducing the urban heat island and the heat load, in comparison with heating costs.

In Athens like in other Mediterranean cities, in spite of the lower energy needed for heating during Winter (-30 to $-50 \%)$, the overall yearly energy consumption in the central area is higher due to the very high demand of energy for cooling during Summer. (Santamouris et al., 2001). Hassid et al. (2000) have confirmed the influence of summer UHI of Athens on cooling energy cost and peak demand (which increase by as much as 100\%). Akbari et al. (2001) studied the Los Angeles UHI and estimate that energy demand increases by 2 to $4 \%$ for each $1^{\circ} \mathrm{C}$ increase in the UHI intensity. Moreover, the authors estimate that $5-10 \%$ of the current electricity demand is spent to cool buildings, just to compensate for the UHI increase since 1940 (about $0.5-3^{\circ} \mathrm{C}$ ). The authors also state that mitigation of the UHI can potentially reduce national energy use in air conditioning by $20 \%$ and save $\$ 10$ billion (US) per year in energy use and improvements in urban air quality. 
Ca et al. (1998) conducted a field study in Japan and concluded that the existence of a park improved the thermal environment in the neighbourhood (the temperature of a busy commercial area $1 \mathrm{~km}$ downwind can be reduced by $\left.1.5^{\circ} \mathrm{C}\right)$. They estimated that within an area of circa $0.5 \mathrm{~km}^{2}$ of the park, $4000 \mathrm{kWh}$ of electricity for cooling (or US\$ 650) can be saved in 1 hour, between 1 and 2 p.m. of a hot summer day; that means a saving of circa $15 \%$ in air cooling electricity. This value is for official buildings and is slightly larger than others obtained for residential buildings (Konopacki $e t$ al., 1996; Meier and Taha, 1997, quoted by Ca et al., 1998).

\subsection{Health}

The effects of the UHI are particularly negative during heat waves. Their consequences depend on the duration and timing of the event and affect mainly the people with pre-existing illness or more stressed due to age or social position. "Illnesses recognisable as the direct exposure to prolonged periods of high environmental temperature are heatstroke, heat exhaustion, heat syncope and heat cramps" (Kilbourne et al., 1982, cited by Dessai, 2002). During the heat waves that occurred recently in Europe, particularly in 2003 (Dessai, 2002; Koppe et al., 2004; WHO, 2009; Gossling et al., 2009; Matzarakis et al., 2009b) the negative influence of UHI on human health and mortality was quite clear. The summer stress for humans is strongly dependent on thermal, air pollution (particularly ozone) and other environmental conditions modified by cities. Moreover, the thermal comfort varies within the urban fabric and consequences on human health differ accordingly. In a study carried out in Strasbourg (Matzarakis et al., 2009 a, b), 2003 and 2004 Physiological Equivalent Temperature (PET) was calculated for five urban sites characterized by different sky view factors and compared to the reference site, which is located in a rural area. The comparison of PET values for the two years shows that PET in 2003 was about 5 to $7 \mathrm{~K}$ higher than in 2004. Furthermore, the diurnal and nocturnal PET were the highest in the city (greatest differences during the night (Matzarakis et al, 2009b, fig.9). During the day, PET was higher in town sites with high sky-view factors than in the country, although the urban site under trees had the lowest PET value.

The possibility of forecasting heat waves requires the knowledge of the thermal bioclimatic conditions, not only in the spatial dimension of urban heat island, but also the vertical component of indoor and outdoor interactions and changes. The development of specific Heat-Health-warning-Systems is a key issue with economic importance. There is also a concern for the increased energy demand during extreme thermal events. 


\section{Planning strategies for a better 'Climate Quality' in towns}

As has been referred, cities give rise to UHI, which according to regional climate may be highly negative. Urban areas increase surface roughness, cause a wind speed decrease (which also enhance UHI and decrease air quality) and emit different sort of pollutants. Some of these consequences may be mitigated by natural means. Thermal, ventilation and air quality aspects have been considered some of the most important for planning purposes (Stock and Beckröge, 1985; Scherer et al., 1997; 1999; Koppe et al., 2004; Baumüller, 2008; Alcoforado et al., 2009a), together with management of urban floods and water resources; the former will be presented in this section.

\subsection{Urban planning at different scales}

Urban planning's role is of paramount importance to inform, coordinate and implement measures to ameliorate climate quality in town in face of urban and global climate change issues (Alcoforado et al., 2009b, fig.23). A proposal of a methodology to introduce climate guidelines in urban planning (carried out at the mesoscale) was put forward for the city of Lisbon but it can be adapted to other cities (Alcoforado et al., 2005; 2009). As planners need spatialized guidelines, a map depicting Lisbon's "homogeneous climatic-response units" or climatopes (Scherer et al., 1999) was prepared and a series of climatic guidelines for planning were put forth for the different units (Alcoforado et al., 2005; 2009). Later, an analysis was carried out at the microscale in a city-district (Telheiras-Lisboa, Alcoforado et al., 2010), with the purpose of defining climatic orientations for this neighbourhood. It was recommended to provide microclimatic diversity, to avoid the creation of excessively confined spaces, to provide shade in some areas (by using deciduous trees, to improve winter sunshine); advice was also given concerning street orientation (avoiding linear buildings normal to prevailing wind direction and Gtype urban typologies that create undesirable whirlwinds. The methodologies were quite different and the research team had to deal with the fact that measures suggested at the meso, and microscale were sometimes conflicting ones.

\subsection{Planning strategies to adapt to both urban and global climate change}

During the last decades, a great number of scientific papers deal with the relationships between "global" climate change and climate modifications due to urbanisation, although the opinions are quite diverse or even antagonic (Parker, 2006; Pielke et al.,2007 Gallo, 2008, McCarthy et al. ,2010 and a great number of other references quoted in Alcoforado and Andrade, 2008). At the same time, governmental or inter- 
national entities are dealing with climate change issues in cities for planning purposes.

The different scenarios proposed by the IPCC must be adapted to the urban reality and planners should be aware that different modifications are to be expected in different cities and within each city district (Alcoforado et al., 2009b). Matzarakis and Endler (2010) have analysed the perspectives of thermal bioclimatic change in a German city (Freiburg) between the periods 1961-90 and 2071-2100 within two IPCC scenarios $\left(\mathrm{A}_{1} \mathrm{~B}\right.$ and $\mathrm{B}_{1}$ ). Based on the assumption that the most modified parameters, within the urban fabric, are the wind speed and radiation fluxes, expressed by the Mean Radiant Temperature (Tmrt), the authors focused on the quantification of these parameters in urban areas (Matzarakis et al., 2000). They further quantified their changes at the end of the $21^{\text {st }}$ century depending on urban morphology and green structure, because Tmrt is modified mainly by buildings and trees. Based on the assumption that, if $\mathrm{Tmrt}=\mathrm{Ta}$ (more or less shady conditions), foreseen changes in heat stress days (PET $>35^{\circ} \mathrm{C}$ ) will be very high. Furthermore, if the wind speed decreases then the number of heat stress days will increase, with the highest changes (an increase of 30 days per year) within $\mathrm{A}_{1} \mathrm{~B}$ scenario for the period 2071-2100. However, for the same scenario $\left(\mathrm{A}_{1} \mathrm{~B}\right)$ and same Tmrt changes, if wind speed increases by $1 \mathrm{~m} / \mathrm{s}$ heat stress days will decrease significantly by the end of the $21^{\text {st }}$ century, compared to original PET conditions.

The undesirable changes can be modified by planting specific vegetation types that produce shade in summer and allow the short wave radiation to reach the surface or the areas where human spend their time in winter.

\subsubsection{Mitigating UHI}

Spatial scale approach of UHI mitigation may be diverse. We will deal here with local and microscale, suggesting solutions to apply to the regions referred to in $\$ 3$ in order to ameliorate climate conditions within the urban fabric.

\section{Green areas}

There seems to be good evidence that planting trees and increasing green areas will contribute to decrease the near surface air temperature (Alcoforado, 1996; Simpson and McPherson, 1998; Spronken-Smith and Oke, 1998; Akbari et al., 2001; Matzarakis, 2001; Shaashua-Bar and Hoffman, 2003; Dimoudi and Nikolopoulou, 2003; Andrade and Vieira, 2005). Grimmond et al. (1996) investigated the influence of trees on local scale surface energy balance fluxes in two suburban neighbourhoods with higher (30\%) and lower (10\%) tree and shrub cover. The conclusion is that at 
the higher tree coverage city-district the latent heat flux and the storage heat flux are increased as a fraction of net all-wave radiation, whereas the sensible heat is decreased. However, due to a greater all wave radiation (lower $\mathrm{K} \uparrow$ and lower $\mathrm{L} \uparrow$ ), in absolute terms there is a greater amount of energy to be dissipated and, above the canopy, temperatures are slightly higher in the neighbourhood with higher tree cover. However, even if trees have little effect on air temperature, they decrease radiant temperature, contributing to lower heat stress (Avissar, 1996; Streiling and Matzarakis, 2003; Spagnolo and de Dear, 2003; Matzarakis and Endler., 2010).

Koppe et al. (2004) present a synthesis of the effects of green areas: vegetation has a lower heat capacity and thermal conductivity than building materials and higher evapotranspiration; plants can filter dust out of the air and reduce wind speed near the ground (positive in hot dry climate, negative in hot humid climates). Consequently, microclimates of nearby areas are (positively) modified.

Shading along streets and parking lots as well as short walking distances are advisable in order to improve human comfort (Koppe et al., 2004). Disadvantageous bioclimatic conditions can be improved, even in case of old 'inherited city structure' by planting trees (Moriyama and Matsumoto, 1988; Gulyás et al., 2003). Other costs and benefits of planning options are synthesized in Koppe et al. (2004). Within the EU funded project BUGS (Benefits of Urban Green Space), an integrated method for assessing the benefits of urban green space is being developed.

In the densely populated city of Guangzhou (China), the municipal government has been implementing various types of greening (Weng and Yang, 2004). However as the primary objective is beautification (the city's nickname is "garden-city"), grass lawns and flowers are favoured, while trees are neglected; Furthermore, urban growth has proceeded at a higher speed than greening. Weng and Yang concluded that "it would require an afforested land of $50 \mathrm{~km}^{2}$ to get completely rid of the $2^{\circ} \mathrm{C}$ UHI" (2004, p.155).

Gill et al. (2007) studied the city of Manchester and showed the role that the green infrastructure can play in adapting for climate change. The results are based on "energy exchange and hydrological models showing surface temperature and surface runoff in relation to the green infrastructure under current and future climate scenarios". This study is important because it highlights the need to quantify and model the potential cooling action and other consequences of different types of green areas, once it is often assumed that all species and ground cover percentage are equally positive in all locations. It further presents the greening of the cities as a way to mitigate UHI, as well as to adapt to climate change. 


\section{Increasing the albedo}

Higher albedo (such as painting the roofs white) may alter the radiation balance and decrease UHI (Givoni, 1989; 1998; Rosenfeld et al., 1995; Bretz et al., 1998). Doulos et al. (2004) define "cold" and "warm" building materials according to their characteristics that affect albedo, colour and surface texture. The rough dark coloured surfaces ("warm" materials) tend to absorb more than the smooth light coloured and flat surfaces ("cold" materials"). However, thermal admittance of building materials must also be considered (Oke et al., 1991).

\section{Modifying building density}

Some authors propose the reduction of building density to mitigate UHI and stress that the climatic effects of various elements of town design should be taken into account: streets' layout and width, street orientation in relation to the prevailing winds, patterns of subdivision of building lots, height, shape and relative location of buildings, (Oke, 1988b; Mills, 1997; Gulyas et al., 2006; Lin et al., 2010; Matzarakis et al., 2010). However, this measure is not adequate to all types of climates (e.g. arid climates).However, some planners advocate the compact cities as a model of sustainable city (Jenks et al., 1996). The consequences of a compact city on climate and air quality are discussed by Mills (2003).

\section{Water surfaces}

Integrating artificial water bodies in arid areas, as it has been shown that even small water bodies lower heat stress index (Saaroni and Ziv, 2003; Andrade, 2003; Alcoforado and Andrade, 2006).

\subsubsection{Controlling Wind}

As mentioned above, cities have influence on wind flow by reducing synoptical wind speed (except in areas where channelling phenomena take place). On the other hand, an UHI may cause advection of cool (and clean) air from the outskirts (country breeze, Barlag and Kuttler, 1990/91) or from the sea (Alcoforado et al, 2006). In areas where very strong winds may occur, prevention strategies must be implemented.

\section{Promoting ventilation}

Several applied urban climatology studies have pointed out the need for ventilation (Stock and Beckröge, 1985; Stock et al., 1986, 1991; Evans and De Schiller, 1996; 
Rosenfeld et al., 1995; Golany, 1996; Baugesetzbuch, 1997; Scherer et al., 1997; Fehrenbach, 1999, Thommes et al., 2001; Baumüller, 2008, Alcoforado et al., 2009).

Ventilation reduction due to urbanization contributes to increased air pollution (negative effect within all regional climates) and increased UHI (negative effect in hot climate or contrasting climates with hot summers). Conversely, in cold climates a decrease of wind speed due to urbanization may have positive effects in terms of human comfort.

A large reduction of natural ventilation potential (up to 10 times) was calculated for Athens (Santamouris et al., 2001). In a project on Lisbon (Alcoforado et al., 2009a), one of the main guidelines to planners was to promote air circulation, not only of prevailing regional winds (from the North or NW) but also of sea breezes. These must be allowed to reach the central city districts in order to mitigate urban heat island and to promote improved air quality standards. This guideline was based on studies of thermal comfort and its perception within the city (Andrade, 2003; Andrade and Alcoforado, 2008: Andrade et al., 2010), as well as of wind field, numerical and physical modelling (Lopes, 2003, Lopes et al., 2011). Ventilation paths for country breezes should also be left free for the same reasons (Barlag and Kuttler, 1990/91; Mayer et al., 1994; Koppe et al., 2004). On the map of the "Guidelines for Planning", produced by the University of Basel, ventilation paths are drawn, along which rugosity may not be enhanced (Scherer et al., 1997; 1999; Thommes et al., 2001)

\section{Dealing with strong wind risks}

On the other hand, risks for humans trees and buildings caused by strong winds occurrences must also be taken into account. In locations where very strong winds are a frequently recurring natural disaster, like in southern China and in Florida, prestorm maintenance (including the selection of appropriate species to match habitat conditions) and post-storm remedial work must be planned efficiently (Jim and Liu, 1997). Even in the so-called temperate climates, wind damages may be very heavy. In December 1999, very strong winds blew over Northern France, due to two very deep depressions, arriving from the Atlantic Ocean, and related to a jet blowing at $400 \mathrm{~km} \mathrm{~h}^{-1}$, at $9000 \mathrm{~m}$ altitude. On December 26, gusts of $169 \mathrm{kmh}^{-1}$ occurred at Paris /Montsouris. In Paris-île de France region, 11 people died and a hundred were seriously injured. In Paris some 6000 trees were violently destroyed and around 7500 in Versailles Park (Lopes, 2003). The research on the different costs of strong wind damage must be carried out by scientists, in collaboration with insurance and civil protection agencies (Abrassart, 1997). In cities, where population density is high, damages and loss of human lives tend to be larger. A study on wind risk assessment in Lisbon based on the cartography of falling trees during windstorm events was carried out in collaboration with the Civil Protection Authority (Lopes et al., 2008). The con- 
clusions and the maps of the most dangerous winds (SW, W) and the main paths followed during windstorms will act as an aid to action during windstorms.

\subsubsection{Controlling air quality factors}

Air pollution and air quality in cities, resulting from a complex interaction between natural and anthropogenic conditions, will remain a serious environmental problem in the future, especially in developing countries (Mayer, 1999, Fenger, 1999, Jacobson, 2002). Indoor air pollution is also a non-negligible factor in urban areas and has to be taken into account (Jones, 1999). Cities with seasonally warm, calm air and sunny weather with high traffic densities tend to be especially prone to the formation of low level ozone and other photochemical pollutants. The associated traffic problems and industrial emissions in large conurbations of the developing world are, in some cases, exacerbated by the geographical setting in inland valleys, leading to seasonally poor ventilation, e.g. Bogota (Valencia and Huertas, 2004) and Delhi (Kare and Kasal, 2004). Night-time maximum $\mathrm{CO}_{2}$ concentration was detected by Grimmond et al. (2002), when measuring and modelling surface-atmosphere exchanges in Chicago, while day-time negative fluxes took place.

Urban air pollution has implications on the local climate and the regional environment (Gotoh, 1993; Raga et al., 2001; Jauregui, 2004). Nevertheless, some aspects of air pollution have been addressed successfully in some megacities through the policies and actions enacted since the 1990's (Jauregui, 2004). Guidelines for the study of urban ventilation and polluted/clean air paths in the urban environment have been discussed by Katzschner (1988), Barlag and Kuttler (1990/91) and Baumüller (2008). In this respect, the charting of pollution wind roses might prove a useful tool (Andrade, 1996; Jauregui, 2002). The complete separation of industry and habitation, originally envisaged as an environmental improvement and a reasonable solution in a society with heavily polluting industries, is now outdated and only leads to increased commuting traffic and congestion (Fenger, 1999). The impacts of urban air pollution can be mitigated by constructive city planning. In the mitigation process, reduction of emission is the key issue. According to some authors (Steemers, 2003; Jenks et al. ed., 2002), the goal is now integrated land use to minimize transport derived emissions and thus total urban emissions. Open spaces and parks can be used and modified by planting trees for reduction of air pollutants (Streiling and Matzarakis, 2003), noise and shading to improve the environmental quality especially in the residential areas. The possibility of rebuilding city-districts is very low but the construction of ring roads, which lead part of the traffic round the city centre, is one option of avoiding air pollution in parts of the towns (Fenger, 1999).

From human biometeorological point of view, the quantification of the air quality in urban areas and urban structures can be carried out by air stress and air quality 
indices. These "enable an assessment of the integral air quality conditions, which are not restricted to single air pollutants and, therefore, reflect the ambient air consisting of a mixture of air pollutants more realistic" (Mayer et al., 2004).

\section{Concluding remarks}

Cities contribute to global climate change because of the agglomeration of population and urban activities (Alcoforado and Andrade, 2008). The expected changes of air temperature to the end $21^{\text {st }}$ century are in the range of the present measured and detected changes of Urban Heat Island. Therefore, nowadays we are already experiencing the expected climate changes in our cities and action is urgently needed.

There is still a need for much research on the topics discussed above. Nevertheless, the large number of recent publications shows that scientists are aware of the importance of developing research on the climate of cities and communicating their results in a way that can be used by planners, architects and decision makers. Furthermore, it is important to be able to quantify the cost of some urban climate features, like the UHI, as well as the benefits of using climate knowledge in the planning processes.

However, there still exist limitations and different points of view between urban climatologists and urban planners, concerning urban planning issues. It has to be made clear that urban climate processes and effects are located between meso and micro scale but usually planners think in different sharp scales. Thus it is urgent to acquire a shared language and dialogue between both communities, as well as to further the debate on the advantages of including climatic guidelines in Master Plans of urban municipalities in a systematic way.

\section{References}

Abrassart, E. (1997): Les risques liés au climat:point de vue d'un réassureur. En Les risques liés au climat, Dijon, Université de Bourgogne, LXXXVII, p. 135-140.

Akbari, H., Pomerantz, M. y Taha, H. (2001): Cool surfaces and shade trees to reduce energy use and improve air quality in urban areas. Solar Energy, 70, 295-310.
Alcoforado, M.J. (1996): Comparaison des ambiances bioclimatiques estivales d'espaces verts de Lisbonne. Publications de l'Association Internationale de Climatologie, 9, p. 273-280.

Alcoforado, M.J. (2010a): Assessing and modeling the urban climate in Lisbon. En Carrega, P (ed) Geographical Information 
and Climatology. London, ISTE y Hoboken, NY, Wiley, p. 125-158.

Alcoforado, M.J. y Andrade, H. (2006): Nocturnal urban heat island in Lisbon (Portugal): main features and modelling attempts. Theoretical and Applied Climatology, 84 (1-3), 151-159. DOI 10.1007/s00704-005-0152-1

Alcoforado, M.J., Andrade, H., Lopes, A., Vasconcelos, J. y Vieira, R. (2006): Observational studies on summer winds in Lisbon (Portugal) and their influence on daytime regional and urban thermal patterns. Merhavim, 6, 90-112.

Alcoforado, M.J., Andrade, H., Lopes, A. y Oliveira, S. (2007): A ilha de calor de Lisboa. Aquisição de dados e primeiros resultados estatísticos para aplicação ao ordenamento urbano. Geophilia - o sentir $e$ os sentidos da geografia, Centro de Estudos Geográficos, Lisboa, p. 593612.http://www.c1ima.org

Alcoforado, M.J. y Andrade, H. (2008): Global warming and urban heat island. En Marzluff, J.M., Shulenberger, E., Endlicher, W., Alberti, M., Bradley, G., Ryan, C., Simon, U. y ZumBrunnen, C. (eds) Urban Ecology, An International Perspective on the Interaction Between Humans and Nature, US, Springer. p. 249-262. http://www.clima.org

Alcoforado, M.J., Andrade, H., Lopes, A. y Vasconcelos, J. (2009a): Application of climatic guidelines to urban planning. The example of Lisbon (Portugal). Landscape and Urban Planning, 90 (1-2), 56-65.

Alcoforado, M.J., Andrade, H., Oliveira, S., Festas, M.J. y Rosa, F. (2009b): Alterações climáticas e desenvolvimento urbano. Série Política de Cidades, 4, DirecçãoGeral do Ordenamento do Território e Desenvolvimento Urbano, Lisboa, 90 p. (availbale at the DGOTDU site)
Alcoforado, M.J., Andrade, H. y Lopes, A. (2010b): Clima e ordenamento urbano na escala microclimática: o exemplo do bairro de Telheiras em Lisboa. En Figueiredo et al (eds), Clima e Recursos Naturais. Conferências de Homenagem ao Prof. Doutor Dionísio Golçalves, IPB, Bragança, 43-82.

Andrade, H. (1996): A qualidade do ar em Lisboa, valores médios e situações extremas. Finisterra- Revista Portuguesa de Geografia, XXXI (61), 43-66. (http://www.ceg.ul.pt/Finisterra)

Andrade, H. (2003): Human Bioclimate and air temperature in Lisbon (in Portuguese). $\mathrm{PhD}$ Thesis, University of Lisbon, 435 p.

Andrade, H. y Vieira, R. (2007): A climatic study of an urban green space: the Gulbenkian Park in Lisbon (Portugal). Finisterra-Revista Portuguesa de Geografia, XLII(84): 27-46. (http://www.ceg.ul.pt/Finisterra)

Andrade, H. y Alcoforado, M.J. (2008): Microclimatic variation of thermal comfort in a district of Lisbon (Telheiras) at night. Theoretical and Applied Climatology. 92(34), 225-237. DOI 10.1007/s00704-0070321-5.

Andrade H.; Alcoforado, M.J. y Oliveira, S. (2010): Perception of temperature and wind by users of public outdoor spaces: relationships with weather parameters and personal characteristics. International Journal of Biometeorology, online first. DOI 10.1007/s00484-010-0379-0

Arnfield, J. (2003): Two decades of urban climate research: a review of turbulence, exchanges of energy and water, and the urban heat island. International Journal of Climatology, 23, 1-26.

Atkinson, B.W. (1971): The effect of an urban area on the precipitation from a moving thunderstorm. Journal of Applied Meteorology, 10, 47-55. 
Atkinson B.W. (2003): Numerical Modelling of urban heat island intensity. BoundaryLayer Meteorology, 109, 285-310.

Avissar, R. (1996): Potential effects of vegetation on the urban thermal environment. Atmospheric Environment, 30, 437-448.

Aynsley, R. y Gulson, L. (1999): Microclimate and urban planning in the humid tropics, $27^{\text {th }}$ RAPI Congress Papers, September 1999, 14 p.

<http://www.lpe.nt.gov.au/devel/planning/rapi/default.htm> (Consulta: 07.2007)

Baker, L.A., Brazel, A.J., Selover, N., Martin, C. McIntyre, N., Steiner, F.R., Nelson, A. y Musacchio, L. (2002): Urbanization and warming of Phoenix (Arizona, USA): Impacts,feedbacks and mitigation. Urban Ecosystems, 6, 183-203.

Barlag, A.B. y Kuttler, W. (1990/91): The significance of country breezes for urban planning. Energy and Buildings, 15-16, 291-297.

Bärring, L. y Mattsson, J. (1985): Canyon geometry, street temperatures and urban heat island in Malmö, Sweden. International Journal of Climatology, 5, 433-444.

Baugesetzbuch (1997): Federal Building Code. Act to Amend the Federal Building Code and to Reorder Spatial Planning Law. Bundesministerium für Verkehr, Bau- und Wohnungswesen, BGBI. 1, 2081p.

Baumüller, J. (2008): Climate booklet for urban development Online -Städtebauliche Klimafibel Online. Ministry of Economy Baden-Württemberg in cooperation with Environmental Protection Department of Stuttgart. http://www.stadtklima-stuttgart. de/index.php?climate_booklet

h t t p:// www . staed tebaulicheklimafibel.de/Climate_Booklet/index1.htm
Bitan, A. (1992): The high climatic quality city of the future. Atmospheric Environment. Part B. Urban Atmosphere. 26(3), 313-329.

Bonan, G.B. (2000): The microclimates of a suburban Colorado (USA) landscape and implications for planning and design. Landscape and Urban Planning, 49, 97114.

Bornstein, R. y Lin, Q. (2000): Urban heat islands and summertime convective thunderstorms in Atlanta: Three case studies. Atmospheric Environment, 34, 507-516.

Brazel, A. y Martin, J. (1997): Town planning, architecture and building. En Thompson y Perry (eds), Applied Climatology. Principles and Practice. London, Routledge, 175-186.

Bretz S., Akbari, H. y Rosenfeld, A. (1998): Practical issues for using solar-reflective materials to mitigate urban heat islands. Atmospheric Environment, 32, 95-101.

Bullen, C.R. (2000): A low energy housing design in an area of high wind and rain. An innovative housing scheme at Stenness on the Orkney Islands. Energy and Buildings, 32, 319-326.

Ca, V.T., Asaeda, T. y Abu, E.M. (1998): Reductions in air conditioning energy caused by a nearby park. Energy and Buildings, 29, 83-92.

Carrega, P. (1994): Topoclimatologie et habitat. Analyse spatiale et appliquée. Revue de Géographie du Laboratoire d'Analyse spatiale Raoul Blanchard, Université de Nice. 408p.

Changnon, S.A. (1974): Recent studies of urban effects on precipitation in the United States. En Urban Climates, WMO, Technical Note, 108, 327-343.

Chen, H., Ooka, R., Harayama, K., Kato, S. y Li, X. (2004): Study on outdoor thermal environment of apartment block in 
Shenzhen, China with coupled simulation of convection, radiation and conduction. Energy and Buildings, 36(12), 1247-1258.

Davenport, A.G. (1965): The relationship of wind structure to wind loading. Proceedings of the Conference on Wind Effects on Structures, Sympos. 16, 1, HMSO, London, 53-102.

Deostali, V. (2000): Impact of the rapid urban growth on heat and moisture islands in Puna City, India. Atmospheric Environment, 34, 2745-2754.

Dessai, S. (2002): Heat stress and mortality in Lisbon part I. Model construction and validation. International Journal of Biometeorology, 47, 6-12.

Dimoudi K. y Nikolopoulou M. (2003): Vegetation in the urban environment: microclimatic analysis and benefits. Energy and Buildings, 35, 69-76.

Doulos, L., Santamouris, M. y Livada, I. (2004): Passive cooling of outdoor urban spaces. The role of materials. Solar Energy, 77, 231-249.

Eliasson, I. (1990/91): Urban Geometry, surface temperature and air temperature. Energy and Buildings, 15-16, 141-145.

Eliasson, I. (1996): Urban nocturnal temperatures, street geometry and land use. Atmospheric Environment, 30, 379-392.

Eliasson, I. (2000): The use of climate knowledge in urban planning, Landscape and Urban Planning, 48, 31-44.

Emmanuel, R. y Johansson, E. (2006): Influence of urban morphology and sea breeze on hot humid microclimate: the case of Colombo, Sri Lanka. Climate Research, 30, 189-200.

Emmanuel, R., Rosenlundb, H. y Johansson, E. (2006): The influence of urban design on outdoor thermal comfort in the hot, humid city of Colombo, Sri Lanka. International Journal of Biometeorology, 51, 119-133

Ettoumi, F.Y., Messen, N., Adane, A.H.M. y Sauvageot, H. (2003): Temperature variations in a housing of the semi-arid region of Djelfa (Algeria). Building and Environment, 38, 511-519.

Evans, J. M. y De Schiller, S. (1996): Application of microclimate studies in town planning: a new capital city, an existing district and urban river front development. Atmospheric Environment, 30, 361-364

Fehrenbach, U. (1999): Analyse und Bewertung lokal- und regionalklimatisch wirksamer Faktoren in der Region Basel, PhD, University of Basel, Stratus, 6, 177 p.

Fenger, J. (1999): Urban air quality. Atmospheric Environment, 33, 4877-4900.

Gallo, K. y Hale, R. (2008): Recognition of the influence of the urban climate in assessment of large-scale temperature trends. Urban Climate News, 29, 5-7. (en línea) <http://www.urban-climate.org/> (Consulta: 02.2010).

Gill, S. (2004): Literature Review; Impacts of Climate Change on Urban environments. Centre for Urban and Regional Ecology, University of Manchester, 72p.

Gill, S., Handley, J., Ennos, A. y Pauleit, S. (2007): Adapting Cities for Climate Change: The Role of The Green Infrastructure. Built Environment, 3(1), 115-133.

Giridharan, R., Ganesan, S. y Lau, S.S.Y. (2004): Daytime urban heat island in highrise and high-density residential developments in Hong Kong. Energy and Buildings, 36, 525-534.

Givoni, B. (1989): Urban design in different climates. Geneva, WMO, TD 336. 
Givoni, B. (1998): Climate Considerations in Building and Urban design. New York, John Wiley and Son.

Goh, K.C. y Chang, C.H. (1999): The relationship between height to width ratios and the heat island intensity at 22:00h for Singapore. International Journal of Climatology, 19, 1011-1023.

Golany, G.S. (1996): Urban design morphology and thermal performance. Atmospheric Environment, 30, 455-465.

Gosling, S.N., Lowe, J.A., McGregor, G.R., Pelling, M. y Malamud, B.D. (2009): Associations between elevated atmospheric temperature and human mortality: a critical review of the literature, Climatic Change, 92, 299-341.

Gotoh, T. (1993): Relation between heat islands and $\mathrm{NO}_{2}$ pollution in some Japanese cities. Atmospheric Environment, 27B, 1, 121-128.

Grady, D.P. y Mote, T.L. (2003): Patterns and causes of Atlanta's urban heat island-initiated precipitation. Journal of Applied Meteorology, 42, 1273-1284.

Grimmond, C.S.B. y Oke, T.R., (1995): Comparison of heat fluxes from summertime observations in the suburbs of four North American cities. Journal of Applied Meteorology, 34, 873-889.

Grimmond, C.S.B., Souch, C. y Hubble, M.D. (1996): Influence of tree cover on summertime energy balance fluxes, San Gabriel Valley, Los Angeles. Climate Research, 6, 45-57.

Grimmond, C.S.B. y Oke, T.R. (1999a): Heat storage in urban areas: Local-scale observations and evaluation of a simple model. Journal of Applied Meteorology, 38, (7), 922-940

Grimmond, C.S.B. y Oke, T.R. (1999b): Rates of evaporation in urban areas. Impacts of
Urban Growth on Surface and Ground Waters. International Association of Hydrological Sciences Publication, 259, 235-243.

Grimmond, C.S.B. y Oke, T.R. (1999c): Aerodynamic properties of urban areas derived from analysis of surface form. Journal of Applied Meteorology, 38, 12621292.

Grimmond, C.S.B., King, T.S., Cropley, F.D., Nowak, D.J. y Souch, C. (2002): Local scale fluxes of carbon dioxide in urban environments: methodological challenges and results from Chicago. Environmental Pollution, 116, 243-254.

Gulyás, A., Unger, J., Baláz, B. y Matzarakis, A. (2003): Analysis of the bioclimatic conditions within different surface structures in a medium-sized city (Szeged, Hungary), Acta Climatologica et Chronologica, Universitatis Szegediensis, 36-36, 37-44.

Gulyás, A, Unger J. y Matzarakis, A. (2006): Assessment of the microclimatic and human comfort conditions in a complex urban environment: modeling and measurements. Building and Environment, 41, 1713-1722.

Hassid, S., Santamouris, M., Papanikolaou, N., Linardi, A., Klitsikas, N., Georgakis C. y Assimakopoulos, D.N. (2000): The effects of the Athens heat island on air conditioning load. Energy and Buildings, 32, 131141.

Helbig, A., Baumüller, J. y Kerschgens, M. (1999): Stadtklima und Luftreinhaltung. ( $2^{a}$ edición) Berlin, Springer.

Holmer, B. y Eliasson, I. (1999): Urban-rural vapor pressure differences and their role in the development of urban heat islands. International Journal of Climatology, 19, 989-1009. http://www.ruf.rice.edu/ sass/UHI.html. 
Hwang, R.L., Matzarakis, A. y Lin, T.P. (2011): Seasonal effect of urban street shading on long-term outdoor thermal comfort. Building and Environment, 46, 863-870.

Jackson, L. (2003): The relationship of urban design to human health and condition. Landscape and Urban Planning, 64, 191200.

Jacobson, M. (2002): Atmospheric Pollution History, Science and Regulation. Cambridge University Press.

Jauregui, E. (1997): Climates of tropical and subtropical cities. En Yoshinom, M., Domrös, M., Douguédroit, A., Paszynski, J. y Nkemdirim, L. (eds) Climates and Societies-a Climatological Perspective. The Geojournal Library. Dordecht, Kluwer Academic Publishers, pp. 361-373.

Jauregui, E. (2002): The climate of Mexico City Air Basin. Its effects on the formation and transport of pollutants. En Fenn, M., de Bauer, L.I. y Hernández-Tejeda, T. (eds), Urban Air Pollution and Forests. Ecological Studies Series, Berlin, Springer, $156 \mathrm{p}$.

Jauregui, E. (2004): Mexico City's air pollution problem. En Elsom, D. y Longhurst, J. (eds), Regional and Local Aspects of Air Pollution Management. Boston, WIT Press, pp. 193-218.

Jauregui, E. y Romales, E. (1996): Urban effects on convective precipitation in Mexico City. Atmospheric Environment 30, 3383-3389.

Jauregui, E. y Tejeda, A. (1997): Urban-rural humidity contrasts in Mexico City. International Journal of Climatology, 17 , 187-196.

Jauregui, E. y Luyando, E. (1999): Global radiation attenuation by air pollution and its effects on the thermal climate on Mexico City. International Journal of Climatology, 19, 683-694.
Jendritzky, G. (1988): Bioklima. En VDIKommission. Reinhaltung der Luft (ed) Stadtklima und Luftreinhaltung, Berlin, Springer, p. 411-426.

Jenks, M., Burton, E. y Williams, K. (eds) (2002): (first published 1996). The compact city: a sustainable urban form? Oxford, Spon Press, p. 350.hopo

Jim, C.Y. y Liu, H.H. (1997): Storm damage on urban trees in Guangzhou, China. Landscape and Urban Planning, 38, (1-2), 45-59.

Jones, A.P. (1999): Indoor air quality and health. Atmospheric Environment, 33, 4535-4564.

Kannari, A., Mikami, T.y Iyumi, T. (2003): Direct effect on temperature rise by anthropogenic heat injection into urban atmosphere. Proc. Fifth International Conference on Urban Climate, 1-5 Sept., Lodz, 1, 193-196.

Kare, M. y Kasal, A. (2004): Sectorial analysis of air pollution control in Delhi. En Elsom, D. y Longhurst, J. (eds), Regional and Local Aspects of Air Pollution Management. Boston, WIT Press, p. 193218.

Katzschner, L. (1988): The urban climate as a parameter for urban development. Energy and Buildings, 11, 137-147.

Kim, Y.H. y Baik, J.J. (2004): Daily maximum urban heat island intensity in large cities of Korea. Theoretical and Applied Clima-tology, 79, (3-4), 151-164.

Kondo, J. y Yamatawa, H. (1986): Aerodynamic roughness over an inhomogeneous ground surface. Boundary-Layer Meteoro$\log y, 35,331-348$.

Koppe, C., Jendritzky, G., Kovats, S., Menne, B., Baumüller, J., Bitan, A., Díaz Jiménez, J., Ebi, K.L., Havenith, G., López Santiago, C., Michelozzi, P., Nicol, F., Matzarakis, A., 
McGregor, G., Nogueira, P.J., Sheridan, S. y Wolf, T. (2004): Heat-waves: risks and responses. Regional Office for Europe. Health and Global Environmental Change, Series No. 2. Copenhagen.

Kumar, R. y Kaushik, S.C. (2005): Performance evaluation of green roof and shading for thermal protection of buildings, Building and Environment. 40, (11), 1505-1511.

Kusaka, H. y Kimura, F. (2004): Thermal effects of urban canyon structure on the nocturnal heat island: numerical experiment using a mesoscale model coupled with an urban canopy mode. Journal of Applied Meteorology, 43, (12), 1899-1910.

Kuttler, W. (2004): Stadtklima. Teil 1: Grundzüge und Ursachen. UWSF-Z. Umweltchem. Ökotox., 16, p. 1-13.

Landsberg, H. (1981): The urban climate. New York, Academic Press.

Lettau, H. (1969): Note on the aerodynamic roughness-parameter estimation on the basis of roughness-element description. Journal of Applied Meteorology, 8, 828-832.

Lin, T.P., Matzarakis, A. y Hwand, R.L. (2010): Shading effect on long-term outdoor thermal comfort. Building and Environment, $45,213-211$

Lopes, A. (2003): Changes in Lisbon's urban climate as a consequence of urban growth. Wind, surface UHI and energy budget. (in Portuguese). PhD Thesis, University of Lisbon, 369p.

Lopes, A., Oliveira, S., Fragoso, M., Andrade, J. y Pedro, P. (2008): Wind risk assessment in urban environments: the case of falling trees during windstorm events in Lisbon. En St elcová, K. et al (eds), Bioclimatology and Natural Hazards, Springer, pp. 55-74.

Lopes, A., Saraiva, J. y Alcoforado, M.J. (2011): Urban boundary layer wind speed reduc- tion in summer due to urban growth and environmental consequences in Lisbon, Environmental Modelling \& Software, 26(2), 241-243.

Lowry, W.P. (1977): Empirical estimation of urban effects on climate: A problem analysis. Journal of Applied Meteorology, 16, 129-135.

Lowry, W.P. (1998): Urban effects on precipitation. Progress in Physical Geography, 22, 477-520.

Magee, N., Curtis, J. y Wendler, G. (1999): The urban heat island effect at Fairbanks, Alaska. Theoretical and Applied Climato$\log y, 64,39-47$.

Martilli, A. (2007): Current research and future challenges in urban mesoscale modelling. International Journal of Climatology, 27(14), 1909-1918.

Masson, V. (2006): Urban surface modelling and the mesoscale impact of cities. Theoretical and Applied Climatology, 84(13), 35-45.

Matzarakis, A. (2001): The thermal component of the urban climate. Wiss. Ber. Meteorol. Inst. Univ. Freiburg No 6 (in german).

Matzarakis, A., Mayer, H. y Iziomon, M.G. (1999): Applications of a universal thermal index: physiological equivalent temperature. International Journal of Biometeorology, 43, 76-84.

Matzarakis, A., Rutz, F. y Mayer, H. (2000): Estimation and calculation of the mean radiant temperature within urban structures, WCASP-50, WMO/TD No. 1026, 273-278.

Matzarakis, A., Röckle, R., Richter, C.J., Höfl, H.C., Steinicke, W., Streifeneder, M. y Mayer, H. (2008): Planungsrelevante Bewertung des Stadtklimas-Am Beispiel von Freiburg im Breisgau. GefahrstoffeReinhaltung der Luft, 68, 334-340. 
Matzarakis, A., Thomsen, F.y Mayer, H. (2009a): Klimawandel und Heizgradtage in Freiburg, Südwestdeutschland. Gefahrstoffe-Reinhaltung der Luft 69, 319-324.

Matzarakis, A., De Rocco, M. y Najjar, G. (2009b): Thermal bioclimate in Strasburg The 2003 heat wave. Theoretical and Applied Climatology, 98, 209-220.

Matzarakis, A. y Endler, C. (2010): Adaptation of thermal bioclimate under climate change conditions - The example of physiologically equivalent temperature in Freiburg, Germany. International Journal of Biometeorology, 54, 479-483.

Matzarakis, A., Rutz, F., Mayer, H. (2010): Modelling Radiation fluxes in simple and complex environments-Basics of the RayMan model. International Journal of Biometeorology, 54, 131-139.

Mayer, H. (1999): Air pollution in Cities. Atmospheric Environment, 33, 4029-4037.

Mayer, H., Beckröge, W. y Matzarakis, A. (1994): Bestimmung von stadtklimarelevanten Luftleitbahnen. UVP-Report, 5/94, 265-267.

Mayer, H., Matzarakis, A. y Iziomon, M.G. (2003): Spatio-temporal variability of moisture conditions within the Urban Canopy Layer. Theoretical and Applied Climatology, 76, 165-179.

Mayer, H., Makra, L., Kalberlah, F., Ahrens, D. y Reuter, U. (2004): Air stress and air quality indices. Meteorologische Zeitschrift, 13 , 395-403.

McCarthy, M.P., Best, M.J. y Betts, R.A. (2010): Climate change in cities due to global warming and urban effects. Geophysical Research Letters, 37, L09705, doi:10.1029/ 2010GL042845

Mills, G. (1997): The radiative effects of building groups on single structures. Energy and Buildings, 25, 21-61.
Mills, G. (2003): The Meteorologically utopian city revisited. Proceedings of the International Conference on urban Climate ICUC-6, 1-4.

Mills, G. (2004): The urban canopy layer heat island. IAUC Newsletter, 4, April, 15-19.

Mills, G. (2006): Progress toward sustainable settlements: a role for urban climatology, Theoretical and Applied Climatology, 84, 69-76.

Moriyama, M y Matsumoto, M, (1988): Control of urban night temperature in semi-tropical regions during summer. Energy and Buildings, 11, 213-219.

Offerle, B., Grimmond, C.S.B., Fortuniak, K., Kłysik, K. y Oke, T. R. (2005): Temporal variations in heat fluxes over a northern European city centre. Theoretical and Applied Climatology, in press.

Oke, T. R. (1982): The energetic basis of the urban heat island. Quart. J. R. Met. Soc., 108, 1-24.

Oke T. R. (1984a): Towards a prescription for the greater use of climatic principles in settlement planning. Energy and Buildings, 7, 1-10.

Oke, T.R. (1984b): Methods in urban climatology. En Kichhofer et al (eds), Applied Climatology, Zürcher Geographischen Schriften, 14, 19-29.

Oke, T. R. (1987): The Urban Boundary Layer, London, Routledge.

Oke, T.R. (1988a): The urban energy balance. Progress in Physical Geography, 2(4), 471508.

Oke, T.R. (1988b): Street design and urban canopy layer climate. Energy and Buildings, 11, 103-113.

Oke, T.R. (1994): Keynote Address to the Technical Conference on Tropical Urban 
Climates (TeCTUC), WMO/TD No. 647,p. 23-27.

Oke, T. R. (1995): The Heat Island Characteristics of the Urban Boundary Layer: Characteristics, Causes and Effects. En Cermak, J.E. et al. (eds.) Wind Climate in Cities, Kluwer Academic, p. 81-107.

Oke, T.R. (2006): Towards better scientific communication in urban climate. Theoretical and Applied Climatology, 84 (1-3), 179-190.

Oke, T.R. (2006): Initial guidance to obtain representative meteorological observations at urban sites. Instruments and observing methods 81. WMO/TD-No. 1250. World Meteorological Organization, Geneva, Switzerland.

Oke, T.R., Johnson, G.T.M, Steyn, D.G. y Watson, I.D. (1991): Simulation of surface urban heat islands under 'ideal' conditions at night. Part 2: Diagnosis of causation. Boundary-Layer Meteorology, 56, 339-358.

Oliveira S., Andrade H. (2007): An initial assessment of the bioclimatic comfort in an outdoor public space in Lisbon, International Journal of Biometeorology, 52(1), 69-84.

Oral, G.K. y Yilmaz, Z. (2003): Building form for cold climatic zones related to building envelope from heating energy conservation point of view. Energy and Buildings, $35,383-388$

Parker, D.E. (2006): A Demonstration That Large-Scale Warming is Not Urban, Journal of Climate, 19 (12), 2882-2895.

Pearlmutter, D., Bitan, A. y Berliner, P. (1999): Microclimatic analysis of compact urban canyons in an arid zone. Atmospheric Environment, 33, 4143-4150.

Pearlmutter, D., Bitan, A. y Berliner, P. (2007): Urban Climatology in arid regions: current research in the Negev desert. Interna- tional Journal of Climatology, 27, 18751885.

Pielke Sr., R.A. et al (2007): Unresolved issues with the assessment of multidecadal global land surface temperature trends, Journal of Geophysical Research, 112, D24S08. doi:10.1029/2006JD008229DOI: 10.1002/wcc. 21

Raga, G. B., Castro, T. y Baumgardner, D. (2001): The impact of megacity pollution on local climate and implications for the regional environment: Mexico City. Atmospheric Environment, 35, 1805-1811.

Ratti, C., Raydan, D. y Steemers, K. (2003): Building form and environmental performance: archetypes, analysis and an arid climate. Energy and Buildings, 35, 49-59.

Richards, K. (2004): Observation and simulation of dew in rural and urban environments. Progress in Physical Geography, 28(1), 76-94.

Rosenfeld, A.H., Akbari, H., Bretz, S., Fishman, B.L., Kurn, D.M., Sailor, D. y Taha, H. (1995): Mitigation of urban heat islands: materials, utility programs, updates. Energy and Buildings, 22, 255265.

Rosenfeld, D. (2000): Suppression of rain and snow by urban and industrial air pollution. Science, 287, 1793-1796.

Rotach, M.W. (1994): Determination of the zero-plane displacement in an urban environment. Boundary Layer Meteorology, 67, 187-193.

Rozoff, C.M., Cotton, W.R. y Adegoke, J.O. (2003): Simulation of St. Louis, Missouri, land use impacts on thunderstorms. Journal of Applied Meteorology, 42, 716738.

Saaroni, H. y Ziv, B. (2003): The impact of a small lake on heat stress in a Mediterranean urban park: the case of Tel 
Aviv, Israel. International Journal of Biometeorology, 47, 156-65.

Sailor, D.J. (1995): Simulated urban climate response to modifications in surface albedo and vegetative cover. Journal of Applied Meteorology, 34 (7), 1694-1704.

Sailor, D.J. y Fan, H. (2002): Modelling the diurnal variability of effective albedo for cities. Atmospheric Environment, 36, 713725.

Sailor, D.J y Lu, L. (2004): A top-down methodology for developing diurnal and seasonal anthropogenic heating profiles for urban areas. Energy and Buildings, 38, 2737-2748.

Sakakibara, Y. (1996): A numerical study of the effect of urban geometry upon the surface energy budget. Atmospheric Environment, 30 (3), 487-496.

Santamouris, M., Papanikolaou, N., Livada, I., Koronakis, I., Georgakis, C., Argiriou A. y Assimakopoulos, D. N. (2001): On the impact of urban climate on the energy consumption of buildings. Solar Energy, 70, 201-216

Sass, R. L. (2003): It's not cool to be hot in Houston. (En línea) http://www.ruf.rice. edu/ sass/UHI.html.

Scherer, D., Fehrenbach, U, Parlow, E. y Beha, H.D. (1997): Klimaanalyse der Region Basel-Technischer Bericht des Forschungsund Anwendungsprojekts KABA mit zehn Klimaanalyse- und Planungshinweiskarten der Region Basel, Eigenverlag MCR Lab., Institut für Meteorologie, Klimatologie und Fernerkundung, Universität Basel.

Scherer, D., Fehrenbach, U., Feigenwinter, C., Parlow, E. y Vogt, R. (1999): Improved concepts and methods in analysis and evaluation of the urban climate for optimising urban planning processes. Atmospheric Environment, 33, 4185-4193.
Scherer, D.U.F. et al. (1999): The urban cold island of Basel, Switzerland - implications from a case study. $15^{\circ}$ International Congress of Biometeorology \& International Conference on Urban Clima-tology, Sydney - Australia, Macquarke University.

Shaashua-Bar, L. y Hoffman, M. E. (2003) Geometry and orientation aspects in passive cooling of canyon streets with trees. Energy and Buildings, 35, 61-68.

Shahgedanova, M. et al. (1997): Some aspects of the three-dimensional heat island in Moscow. International Journal of Climatology, 17, 1451-1465.

Shepherd, J.M. (2005) A review of current investigations of urban-induced rainfall and recommendations for the future. Earth Interactions, 9(12), 1-27. bttp://irina.eas.gatech.edu/irina/EAS_Spri ng2008/Shepherd2005.pdf

Simpson, J.R. y McPherson, E.G. (1998): Simulation of tree shade impacts on residential energy use for space conditioning in Sacramento. Atmospheric Environment, 32, 69-74

Spagnolo, J. y De Dear, R. (2003): A field study of thermal comfort in outdoor and semi-outdoor environment in subtropical Sydney. Building and Environment, 38, 721-738.

Spronken-Smith, R. y Oke, T.R. (1998): The thermal regime of urban parks in two cities with different summer climates. International Journal of Remote Sensing, 19(11), 2085-2104.

Steemers, K. (2003): Energy and the city: density, buildings and transport. Energy and Buildings, 35, 3-14.

Steinecke, K. (1999): Urban climatological studies in the Reykjavik subarctic environment. Atmospheric environment, 33, 41574162 . 
Stock, P. y Beckröge, W. (1985): Klimaanalyse Stadt Essen. Essen, Kommunalverband Ruhrgebiet, $22 \mathrm{p}$.

Stock, P., Beckröge, W., Kiese, O. y Kuttler, W. (1986): Klimaanalyse Stadt Dortmund. Essen Kommunalverband Ruhrgebiet, 39p.

Stock, P., Beckröge, W. y Barlag, A.B. (1991): Klimaanalyse Stadt Bochum. Essen, Kommunalverband Ruhrgebiet, 123p.

Streiling, S. y Matzarakis, A. (2003): Influence of singular trees and small clusters of trees on the bioclimate of a city-a case study. Journal of Arboriculture, 29, 309-316.

Svensson, M. K., Eliasson, I. y Holmer, B. (2002): A GIS based empirical model to simulate air temperature variations in the Göteborg urban area during the night. Climate Research, 22, 215-226.

Thommes, W., Parlow, P., Paul, P., Go mann, H. y Schaub, O. (2001): Klima und Raumplanung. Reklip, Final Report, $\mathrm{n}^{\circ} 4$, Coprur ed., Strasbourg.

Tso, C.P. (1996): A survey of urban heat island studies in two tropical cities. Atmospheric Environment, 30(3), 507-519.

Upmanis, H. (1999): The influence of green areas on nocturnal temperatures in a high latitude city (Göteborg, Sweden). International Journal of Climatology,18, 681-700.

Valencia, A. y Huertas, J. (2004): Air quality in Bogota. En Elsom, D. y Longhurst, J. (eds), Regional and Local Aspects of Air Pollution Management. WIT Press, Boston, p 193218.

VDI (eds) (1988): Stadtklima und Luftreinbaltung. Berlin, Springer-Verlag.
VDI (1998): Environmental meteorology. Methods for the human biometeorological evaluation of climate and air quality for urban and regional planning at regional level. Part I: Climate. Berlin, Beuth.

Weng, Q. y Yang, S. (2004): Managing the adverse thermal effects of urban development in a densely populated Chinese city. Journal of Environmental Management, 70, 145-156.

WHO (2009): Global health risks: mortality and burden of disease attributable to selected major risks. Geneva, World Health Organization.

Wienert, U. (2002): Untersuchungen zur Breiten- und Klimazonenabhängigkeit der urbanen Wärmeinsel. Essener Ökologische Schriften, 16, p. 211.

Wienert, U. y Kuttler, W. (2005): The dependence of the urban heat island intensity on latitude-A statistical approach, Meteorologische Zeitschrift, 14(5), 677-686.

Wilmers, F. (1997): Interactions of man and climate in the urban climate-The influence of urbanization on the local climate and the influence of urban climate on man. En Yoshino, M., Domrös, M., Douguédroit, A., Paszinski, J. y Nkemdirim, L. (eds) Climates and Societies-a Climatological Perspective. The Geojournal Library. Dordecht. Kluwer Academic Publishers, p. 334- 359.

Zrudlo, L.R. (1988): A climatic approach to town planning in the Artic. Energy and Buildings, 11, 41-63. 